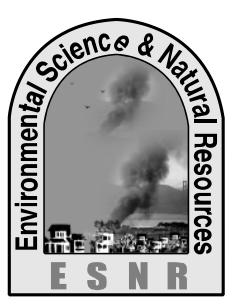

\title{
Investigation of Effluent Quality from an Effluent Treatment Plant of a Textile Industry, Fakir Knitwear Ltd. Narayangonj, Bangladesh
}

\author{
M. R. H. Sarker, A. Razzaque, M. M. Hoque, S. Roy*, M. K. Hossain \\ Department of Environmental Science and Resource Management, \\ Mawlana Bhashani Science and Technology University, Tangail-1902, Bangladesh \\ * Corresponding author: shimul_esrm@yahoo.com
}

\begin{abstract}
Textile industries are the major contributor to environmental pollution and health hazards by generating huge amount of effluents that contain several pollutants and coloring agents. The concentration of these pollutants can be reduced to the permissible limit with the help of an Effluent Treatment Plant (ETP). The study was conducted to observe the textile effluent management techniques of an Effluent Treatment Plant (ETP) of Fakir Knitwear Limited (FKL), Narayanganj, Bangladesh. FKL set up a biological treatment plant to treat the effluent generated by the industry. Different effluent quality parameters were investigated at different stages in ETP. The effluent of the outlet was dark colored probably because of soluble coloring materials of the effluent but it is comparatively better than that of raw wastewater. There were found higher EC values than the standards which indicated that the greater amount of salts in the water due to dumping of solid wastes and discharging of industrial effluents. The highest TDS value 2054 ppm was observed at the screening pit unit than the other parts of the ETP. The highest DO was found $4.58 \mathrm{ppm}$ in clarification tank which was within the standard value of aquaculture. The study also showed that the lowest BOD (24 ppm) and COD (145 ppm) was found at the outlet which was comparatively better than others. Although the effluent from the outlet contained pollutants, these effluent quality was comparatively good than the untreated waste water discharged from the industry. After treatment, the effluent of outlet moderately ensures the standard quality for aquaculture and irrigation. The results suggested that it is obvious to run the ETP regularly to improve the quality of effluents to save our native environment from the harmful effects of wastewater.
\end{abstract}

Key words: Effluent, Effluent treatment plant, Fakir knitwear limited

\section{Introduction}

Industrial wastes are major sources of pollution in all environments and require on-site treatment before discharge into sewage system (Emongor et al., 2005). The rapid industrialization is accompanied by both direct and indirect adverse effect on environment. The rate of contamination of natural water bodies increases with increased industrialization (Senthil et al., 2012). The third world countries especially Bangladesh is now in a vulnerable position. Bangladesh has now more than 30,000 industrial units of which about 24,000 are small and cottage industries (Nuruzzaman et al., 1998). Production for all industrial groups has increased by $46 \%$ since 1981, with some groups such as tannery products, industrial chemicals, pharmaceuticals and garment products increasing by 200 to $4,000 \%$ over the last ten years (DoE, 1991). These textile industries uses large quantity of water in its production processes, resulting in highly polluted and toxic waste waters are discharged into sewers and drains without any kind of treatment. The textile dyeing industries of Gazipur and Narayanganj generate large amount of effluents and sewage sludge on a regular basis which are being directly discharged into the surrounding channel, agricultural fields, irrigation channels, surface water; and these finally enter into Turag and Shitalakkhya River (Sultana et al., 2009). In Bangladesh, industrial wastes and effluents are being discharged at random without treatments directly to soil, canals, and rivers. The solid wastes are also used in land filling. They pollute our soils and natural water systems as well as ground water endangering human health, aquatic lives, and crop production in Bangladesh (Begum et al., 2011). In Bangladesh, unplanned clustered development of industries leads to adverse environmental consequences in an alarming way. Huge amount of water required every day in a dyeing and textile industries and generatingtoxic wastewater rich in dye and chemicals and direct discharge result in severe environmental pollution. These untreated industrial effluents not only deteriorate surface water quality but also cause many water borne diseases that is threatening to public health (Sultana et al., 2013). The rise in the number of industries in Bangladesh, including textile dyeing operations, has seriously increased the pollution that the country is experiencing. In accordance with the Act and Environmental Rules (1997) it is mandatory for textile dyeing factories to install effluent treatment plants (ETPs) to treat wastewater before it leaves the factory premises (ECR, 1997). International pressure for effluent treatment is also increasing and many international buyers are now showing more concern over whether or not textiles are produced in an environmentally friendly way. This trend means that in the future it is likely that installation and operation of an ETP will be essential to sustain business in the competitive world market. It is a positive sign that many industries are also making progress in establishing and operating their own ETPs to comply with national and international requirements, and also because of increased personal awareness of the negative impacts of industrial effluent (Islam et al., 2006; Metcalf and Eddy, 2003). However, in order for these ETPs to function effectively and meet national standards they require regular and proper monitoring. Untreated and treated wastewater characteristics need to be known and must be monitored regularly to evaluate the efficiency of the treatment plant. The present study was conducted to investigate the effluent quality discharging by ETP of Fakir Knitwear's Ltd. and to comparison of parameters with different standards. 


\section{Materials and Methods}

The study area was located at Narayanganj an Upazila in Narayanganj District (Fig. 1), Bangladesh, which is called the Dundee of East due to the presence of jute mills. The district is pioneer in merchandising thread and dying items. The ETP of Fakir Knitwear's Ltd. is established at $23^{\circ} 47^{\prime} 3.47^{\prime \prime} \mathrm{N}$ latitude and 90³5'14.70"E longitude (Fig. 1).

\section{Sample collection}

Seven representative water samples were collected from seven different points (Table 1) in $500 \mathrm{ml}$ dark plastic

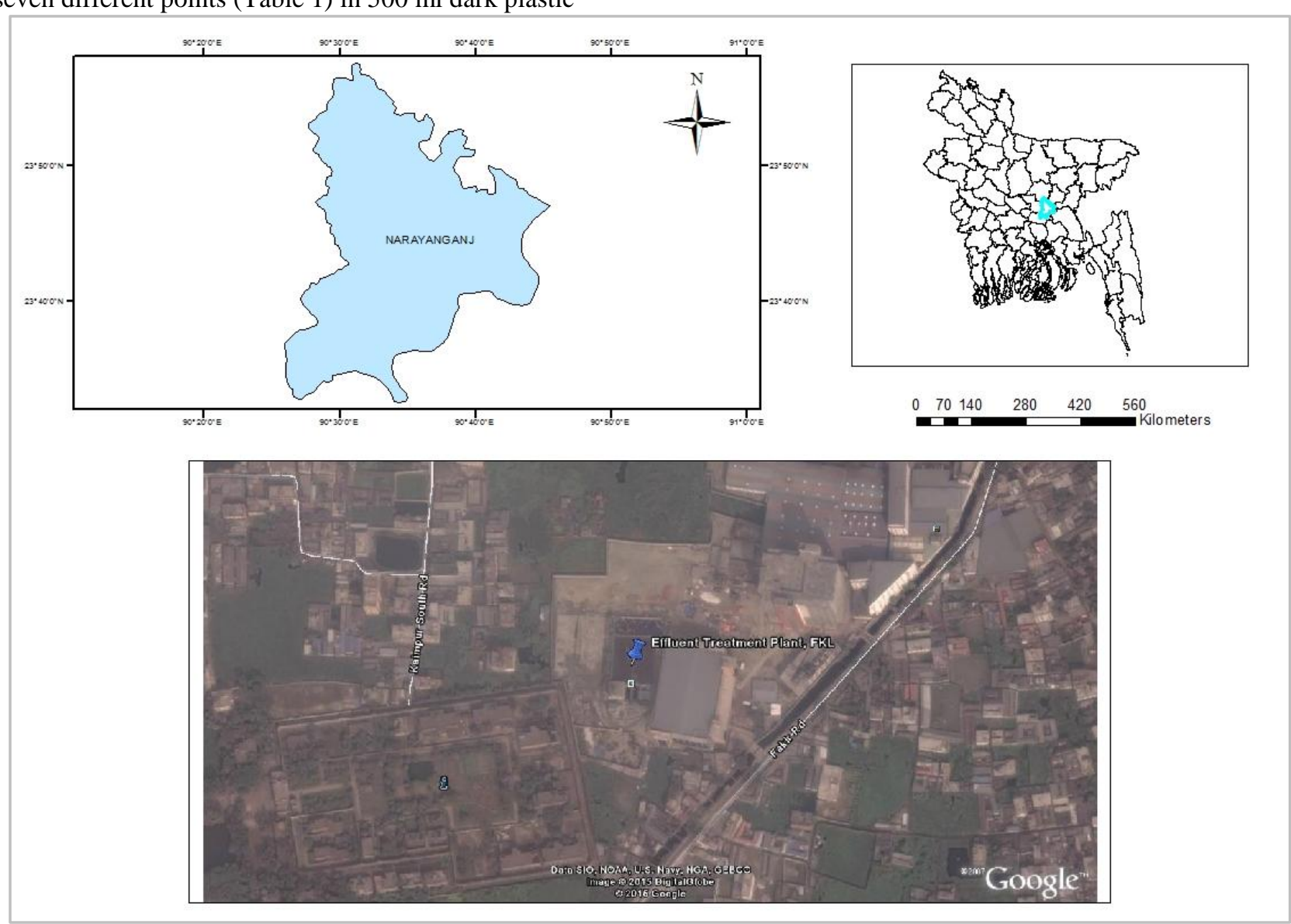

Fig. 1. Map showing the effluent treatment plant of Fakir Knitwear Ltd. at Narayanganj district

Table 1. Sampling stations in the study area

\begin{tabular}{c|c|c}
\hline Sl. No. & Sampling stations & Name of the sampling stations \\
\hline 1 & $\mathrm{~S}_{1}$ & Inlet \\
2 & $\mathrm{~S}_{2}$ & Storage tank \\
3 & $\mathrm{~S}_{3}$ & Neutralization tank \\
4 & $\mathrm{~S}_{4}$ & Distribution tank \\
5 & $\mathrm{~S}_{5}$ & Oxidation tank \\
6 & $\mathrm{~S}_{6}$ & Sedimentation tank \\
7 & $\mathrm{~S}_{7}$ & Clarification tank/Out let \\
\hline
\end{tabular}




\section{Analytical methods}

The following analyses were done from the collected water samples: color and odor, temperature, $\mathrm{pH}$, electrical conductivity (EC), total dissolved solid (TDS), dissolved oxygen (DO), biological oxygen demand (BOD), and chemical oxygen demand (COD). To provide necessary information for each sample such as date of collection, location, time, etc. were recorded in the note book and each sample collected in a plastic bottle was labeled separately with a unique identification number. The color and odor was observed with naked eye and nose, respectively. The water quality parameters such as temperature and $\mathrm{pH}$ were determined by the thermometer and digital $\mathrm{pH}$ meter (model-pH Scan WP 1, 2, Malaysia), respectively. Buffer solution containing $\mathrm{pH} 7.0$ was used to calibrate the digital $\mathrm{pH}$ meter. Electric conductivity (EC) and total dissolved solids (TDS) were determined by digital EC meter and digital TDS meter (model-HM digital, Germany), respectively. Dissolved oxygen (DO) was determined by digital DO meter (model-D. 46974, Taiwan) where sodium thiosulphate $(0.025 \mathrm{~N})$ was used as a reagent. Alkalinity was measured by titration method and the EDTA method was used to determine the hardness of water. The biological oxygen demand (BOD) was measured by two steps where initial BOD
$\left(\mathrm{BOD}_{1}\right)$ was measured immediately after collection and after 5 days BOD $\left(\mathrm{BOD}_{5}\right)$ was measured by incubation in the dark condition at $20^{\circ} \mathrm{C}$ for 5 days. Then the total $\mathrm{BOD}\left(\mathrm{BOD}_{1}-\mathrm{BOD}_{5}\right)$ was measured according to Trivedy and Goel (1984), and Huq and Alam (2005).

\section{Results and Discussion}

The chemical parameters of water in the ETP of FKL obtained from the analyses are described in Table 2. The color of effluents is observed visually. The observed color of the effluent was slightly wine red and emits pungent smell which means the water is polluted and dangerous for aquatic ecosystem and human health. The effluent at every part emits noxious smell which indicate that the water is polluted and dangerous for aquatic ecosystem and human health which also violated the standard values (De, 2005). The $\mathrm{pH}$ value 7.05 (Fig. 2) was found after treatment is ensure the standard value (ADB 1994 and ECR 1997), and the lowest $\mathrm{pH}$ value 7.05 (Table 2) at the outlet ensure the standard values (6.5-8.5) (ECR 1997) respectively. Water that contains more than $1000 \mathrm{ppm}$ of dissolved solids usually contains minerals that give it a distinctive taste or make it unsuitable for human consumption. A maximum TDS value of $400 \mathrm{ppm}$ is permissible for diverse fish production (Chhatwal, 1998).

Table 2. Physicochemical composition of the effluent of various sampling parts of ETP in Fakir Knitwear's Ltd.

\begin{tabular}{|c|c|c|c|c|c|c|c|}
\hline \multirow{2}{*}{$\begin{array}{c}\text { Sampling } \\
\text { stations }\end{array}$} & \multicolumn{7}{|c|}{ Physicochemical parameters } \\
\hline & DO (ppm) & pH & TDS (ppm) & $\mathrm{EC}\left(\mu \mathrm{scm}^{-1}\right)$ & Temperature $\left({ }^{0} \mathrm{C}\right)$ & BOD (ppm) & COD (ppm) \\
\hline $\mathrm{S}_{1}$ & 1.2 & 9.35 & 2054 & 1870 & 39 & 110 & 302 \\
\hline $\mathrm{S}_{2}$ & 1.8 & 8.51 & 1846 & 1860 & 38.4 & 106 & 315 \\
\hline $\mathrm{S}_{3}$ & 2.1 & 7.65 & 1750 & 1850 & 38.3 & 94 & 280 \\
\hline $\mathrm{S}_{4}$ & 2.19 & 7.68 & 1753 & 1850 & 38.4 & 96 & 278 \\
\hline $\mathrm{S}_{5}$ & 2.8 & 6.88 & 1747 & 1860 & 38.6 & 78 & 220 \\
\hline $\mathrm{S}_{6}$ & 3.15 & 6.9 & 1746 & 1860 & 38.2 & 61 & 185 \\
\hline $\mathrm{S}_{7}$ & 4.58 & 7.05 & 1755 & 1850 & 37 & 24 & 145 \\
\hline Range & 1.2 to 4.58 & 6.88 to 9.35 & 1746 to 2054 & 1850 to 1870 & 37 to 39 & 24 to 110 & 145 to 315 \\
\hline Mean \pm SD & $2.5 \pm 1.1$ & $7.7 \pm 0.9$ & $1807.3 \pm 114.5$ & $1857.1 \pm 7.5$ & $38.3 \pm 0.62$ & $81.3 \pm 30.3$ & $246.4 \pm 64.1$ \\
\hline
\end{tabular}

The TDS value obtains in outlet (1755 ppm) (Fig. 3) of ETP is moderately equal to subsoil standard value (2100 ppm) of ECR (1997). In the outlet the DO was found $4.58 \mathrm{ppm}$ (Fig. 6), which is within the acceptable limit (4-6 ppm) (De, 2005) but lowers than the drinking standard values (6 or above) (ECR, 1997). DO levels below 1 ppm will not support fish, below 2 ppm may lead to the death of most fishes (EQS, 1997). DO content should be above $6.0 \mathrm{ppm}$ for drinking water and more than $5.0 \mathrm{ppm}$ is suggested for fisheries, recreation and irrigation (EQS, 1997). The BOD value $24 \mathrm{ppm}$ (Fig. 4) of outlet which is discharged into the environment follows the standard of the subsoil water (ECR, 1997). The highest value of COD was found
$315 \mathrm{ppm}$ (Fig. 5) in the storage tank, which is very harmful for the environment. The DO below $2 \mathrm{mg} / \mathrm{l}$ may lead to the death of most fishes in fresh water (EGIS II, 2002). The lowest value of COD was $145 \mathrm{ppm}$, found in the outlet, standard for subsoil water (ECR, 1997). All the textile factories had their effluent temperatures between $34.7^{\circ} \mathrm{C}$ and $48.8^{\circ} \mathrm{C}$, which are higher than the set limit by the National Environmental Quality Standards (BNEQS, 2000). EC is used to indicating the total concentration of ionized constituents of water (Huq and Alam, 2005). The EC value 1850 $\mu \mathrm{scm}^{-1}$ (Table 2 and Fig. 7), observed after treatment is higher than the standard value $\left(1200 \mu_{\mathrm{scm}}^{-1}\right)$ (ECR 1997). 


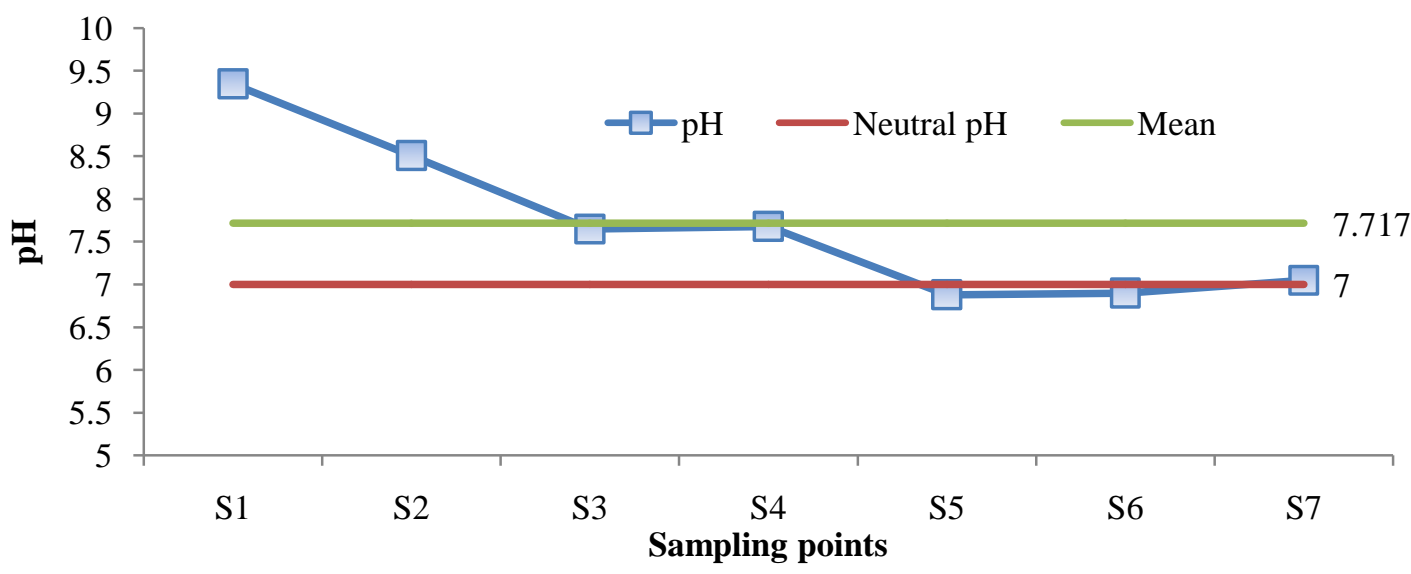

Fig. 2. The values of $\mathrm{P}^{\mathrm{H}}$ at different sampling points and the comparison of value with mean and neutral value

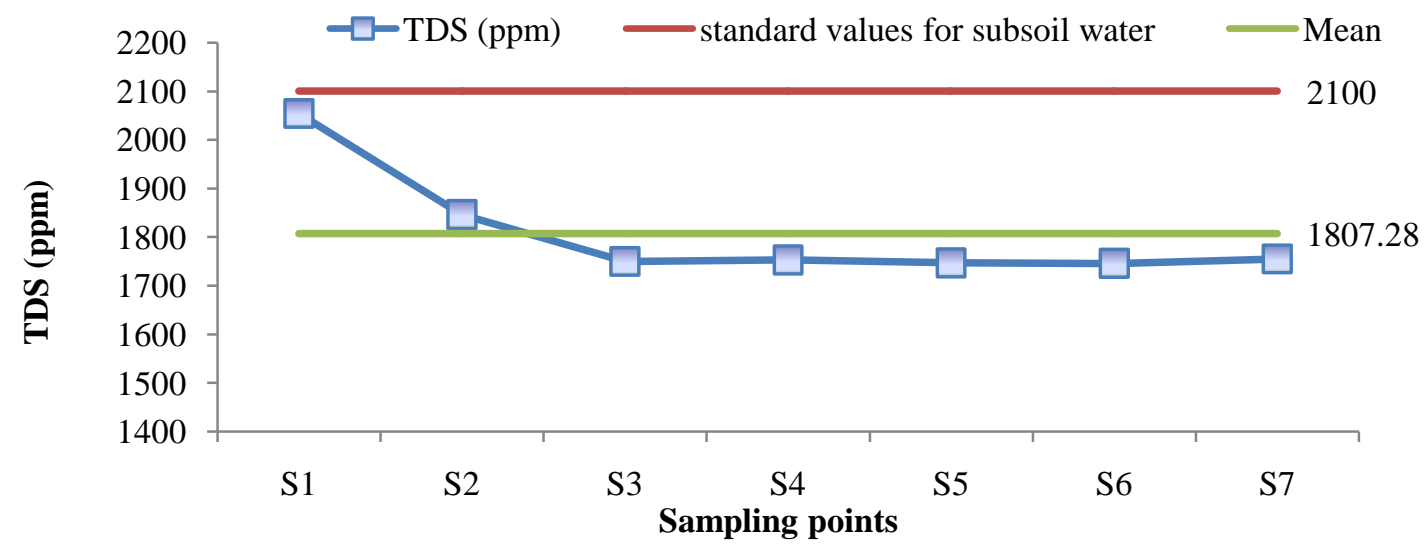

Fig. 3. The values of TDS at different sampling points and the comparison of values with mean and standard of ECR, 1997

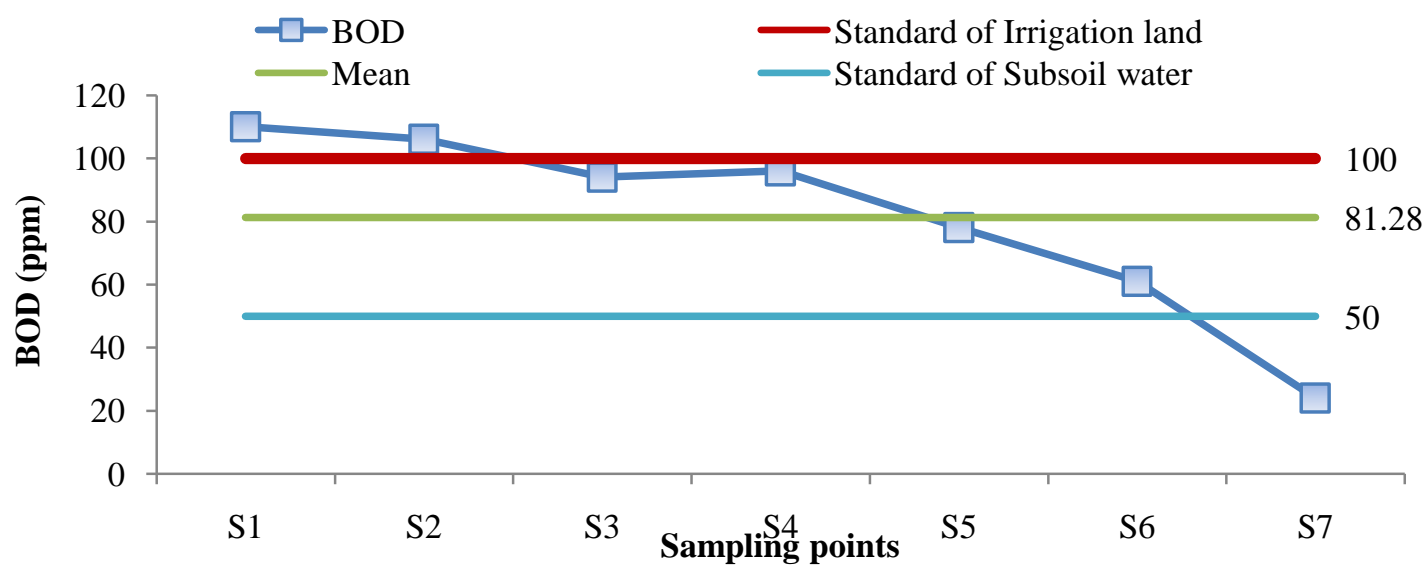

Fig. 4. The values of BOD at different sampling points of ETP and the comparison of values with mean and standard of ECR, 1997 


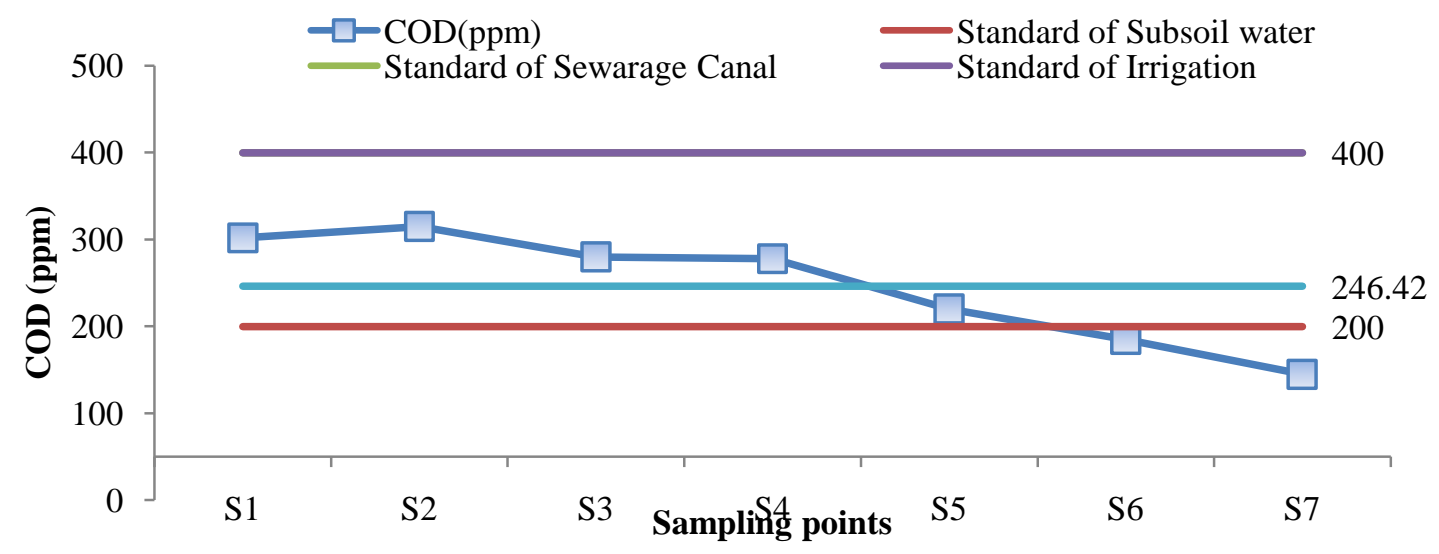

Fig. 5. The values of COD at different sampling points of ETP and the comparison of values with mean and standard of ECR, 1997

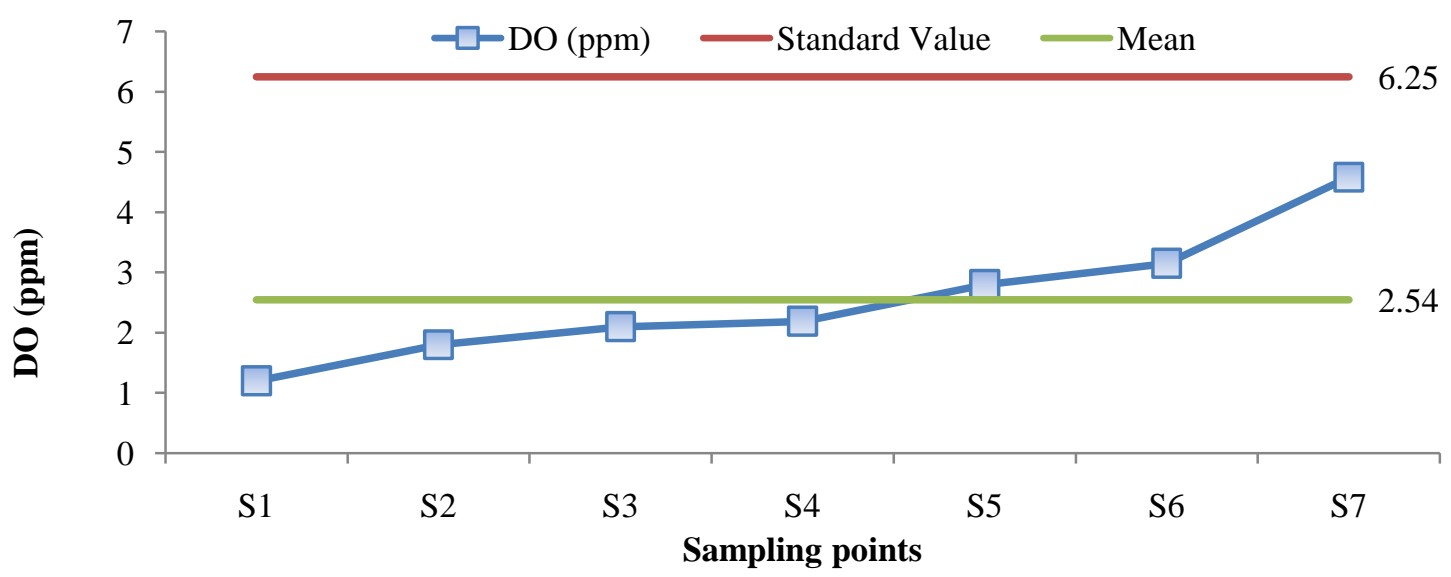

Fig. 6. The values of DO at different sampling points of ETP, and the comparison of values with mean and standard of ECR, 1997

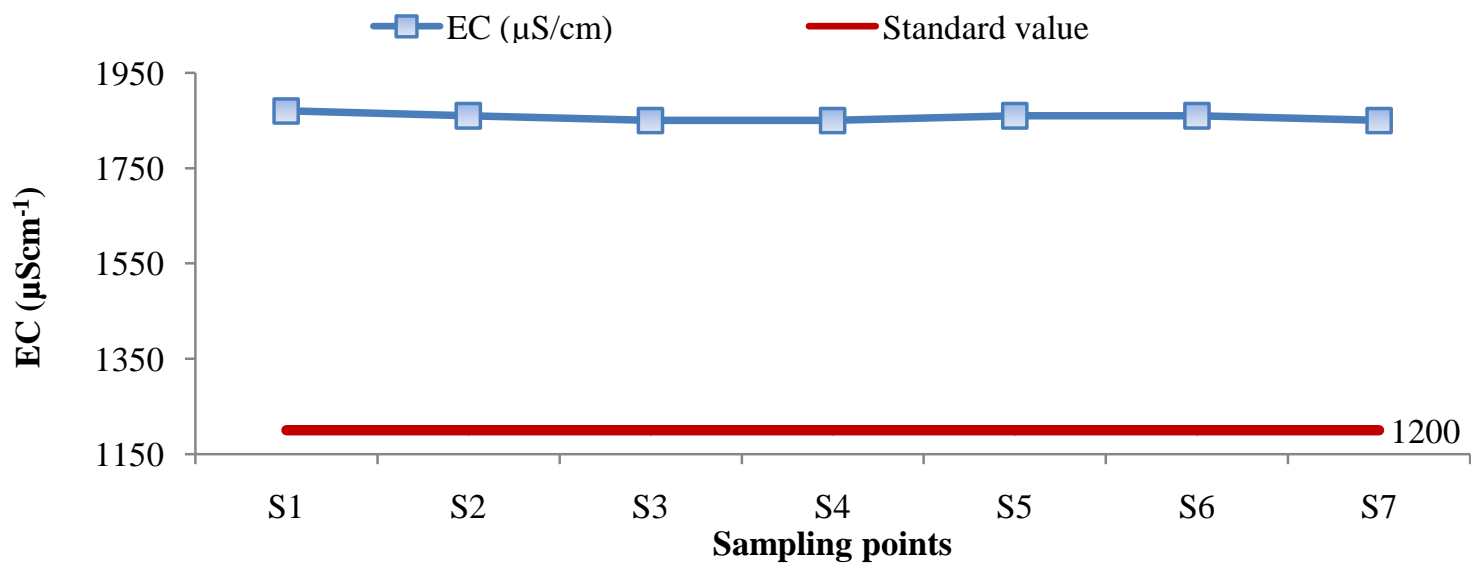

Fig. 7. The values of EC at different sampling points of ETP, and the comparison of values with standard of ECR, 1997

The Fig. 8 shows the values of TDS 2054 ppm which is very higher than the standard value of drinking (1000 ppm) (ADB, 1994) and after treatment the value is 1755 ppm which is also higher than the standards. The figure also showed the EC value, where the value of before treatment $\left(1870 \mu \mathrm{scm}^{-1}\right)$ and after treatment $(1850$ $\mu \mathrm{scm}^{-1}$ ) are higher than the standard value $1200 \mu \mathrm{scm}^{-1}$ (ECR, 1997). The value of BOD before treatment was 110 ppm (Fig. 8) which is not good for aquaculture and the value of BOD after treatment was 24 ppm (Fig. 8) 
which is also not very good for aquaculture. The COD value after treatment is suitable for irrigation standard value (400 ppm) according to ECR (1997).

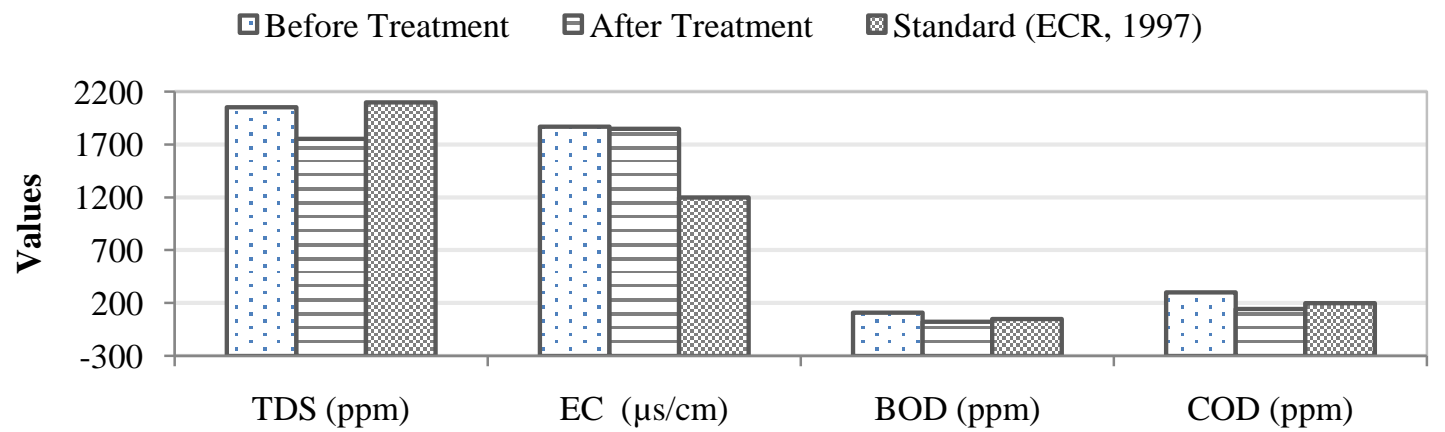

\section{Parameters}

Fig. 8. The comparisons of different parameters between before, after treatment and standard

The value of $\mathrm{P}^{\mathrm{H}}$ before treatment was 9.35 (Fig. 8) which is not good for domestic, drinking, fish-culture and irrigation and the value of $\mathrm{P}^{\mathrm{H}}$ after treatment was 7.05 which is within the standard value (6-9) (ECR,
1997). The value of DO before treatment was $1.2 \mathrm{ppm}$ which is not good for fish-culture but after treatment the DO value $(4.58 \mathrm{ppm})$ satisfies the standard value (4-6 ppm) (ECR, 1997).

\section{Comparison between treated and untreated effluent}

Table 3. Comparison of water quality parameters between the outlet of ETP and the standards

\begin{tabular}{c|c|ccccc}
\hline \multirow{2}{*}{$\begin{array}{c}\text { Water quality } \\
\text { parameter }\end{array}$} & \multirow{2}{*}{$\begin{array}{c}\text { Present study } \\
\text { (Outlet quality) }^{*}\end{array}$} & $\begin{array}{c}\text { Domestic water } \\
\text { standard }^{\mathbf{a}}\end{array}$ & $\begin{array}{c}\text { Drinking quality } \\
\text { standard }^{\mathbf{b}}\end{array}$ & $\begin{array}{c}\text { Fish culture } \\
\text { standard }^{\mathbf{c}}\end{array}$ & $\begin{array}{c}\text { Irrigation } \\
\text { standard }^{\mathbf{d}}\end{array}$ & $\begin{array}{c}\text { Sewage } \\
\text { canal }^{\mathrm{e}}\end{array}$ \\
\hline $\mathrm{P}^{\mathrm{H}}$ & 7.05 & $6.5-8.5$ & $6.5-8.5$ & $6.5-8.0$ & $6.5-8.5$ & $6-9$ \\
$\mathrm{EC}(\mu \mathrm{s} / \mathrm{cm})$ & 1850 & $\mathrm{~N} / \mathrm{A}$ & $\mathrm{N} / \mathrm{A}$ & $\mathrm{N} / \mathrm{A}$ & 750 & 1200 \\
$\mathrm{TDS}(\mathrm{ppm})$ & 1755 & 500 & 1000 & $<400$ & $<450$ & 2100 \\
$\mathrm{DO}(\mathrm{ppm})$ & 4.58 & $4.0-6.0$ & $\mathrm{~N} / \mathrm{A}$ & 5.0 & $\mathrm{~N} / \mathrm{A}$ & $4.5-8$ \\
$\mathrm{BOD}(\mathrm{ppm})$ & 24 & $\mathrm{~N} / \mathrm{A}$ & $\mathrm{N} / \mathrm{A}$ & $<5.0$ & $100^{\mathrm{e}}$ & 250 \\
$\mathrm{COD}(\mathrm{ppm})$ & 145 & $200^{\mathrm{e}}$ & $4^{\mathrm{e}}$ & $\mathrm{N} / \mathrm{A}$ & $400^{\mathrm{e}}$ & 400 \\
\hline
\end{tabular}

Note: N/A= Not Applicable. Source: ${ }^{\mathrm{a}}$ De (2005), ${ }^{\mathrm{b}}$ ADB (1994), ${ }^{\mathrm{c}}$ Meady (1998), ${ }^{\mathrm{d}}$ Ayers and westcot (1976), ${ }^{\mathrm{e}}$ ECR (1997)

\section{The co-relationship between different values}

When there are more dissolved solid in the water body then there is a chance to trap the heat in the water body. The pure water can trap less heat than the dissolved solid rich water. DO is the amount of oxygen dissolved in water while the BOD is the amount of oxygen used by the biological organisms during biodegradation. When BOD level is high, DO level decrease because the oxygen available in the water is being consumed by the bacteria (Sawyer et al., 2003). Therefore, when BOD is high in water the amount of DO is low. More the oxidizable organic matter present in the water, more the BOD (Gupta, 2001). The values of $\mathrm{P}^{\mathrm{H}}$ increasing with increasing BOD (Fig. 9).

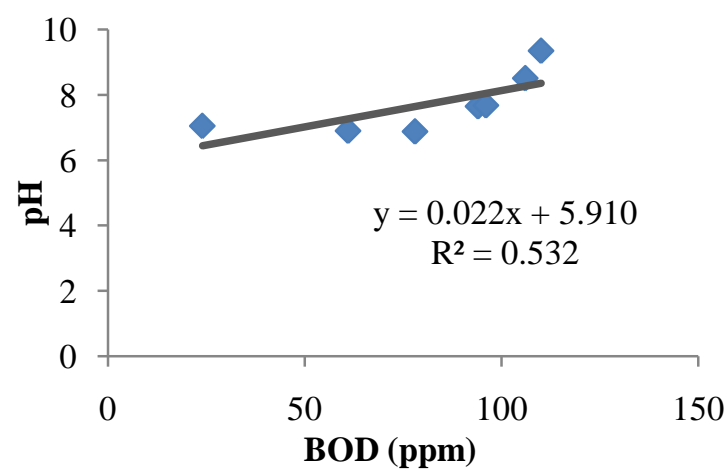

Fig. 9. Correlation between $\mathrm{P}^{\mathrm{H}}$ and $\mathrm{BOD}$ 


\section{Conclusions}

The textile dyeing industries of Narayangonj generate large amount of effluents, sewage sludge and solid waste materials everyday which are being directly discharged into the surrounding channel, agricultural fields, irrigation channels, surface water and these finally enter in to Sitalykha River. The present status of effluents which are discharging into the channel or into the nearby canal is not satisfactory. They only try to control the $\mathrm{P}^{\mathrm{H}}$, DO and BOD in the outlet but the values of COD, TDS, EC and temperature in the outlet are not suitable for the irrigation, aquaculture, drinking and washing purposes. The color of the effluent was wine

\section{Acknowledgment}

The authors are grateful to Central laboratory of Bangladesh University of Engineering and Technology

\section{References}

ADB (Asian Development Bank). 1994. Training manual for environmental monitoring. USA: Engineering Science Inc., pp. 2-16.

Ahmed, F. and Hossain, A. 2011. Design evaluation of an effluent treatment plant, $4^{\text {th }}$ Annual Paper Meet and $1^{\text {st }}$ Civil Engineering Congress.

Ayers, R. S. and Westcot, D.W. 1976. Water Quality for Agriculture. FAO irrigation and drainage paper, 29.

Begum, R. A.; Zaman, M. W.; Mondol, A. T. M. A. I.; Islam, M. S. and Hossain, K. M. F.2011.Effects of textile industrial waste water and uptake of nutrients on the yield of rice, Bangladesh J. Agril. Res., 36(2): 319331.

BNEQS (Bangladesh National Environmental Quality Standard). 2000. Bangladesh Gazette, Registered, Ministry of Environment and Forest (MoEF), Government of the people's republic of Bangladesh.

Chapman, D. 1996. Water Quality Assessment: A Guide to the Use of Biota, Sediments and Water in Environmental Monitoring. $2^{\text {nd }}$ Edition, UNESCO/ WHO/ UNEP.

De, A. K. 2005. Environmental Chemistry. $6^{\text {Th }}$ edition. New age Intermational (p) Ltd., New Delhi, India.

DoE (Department of Environment). 1991. Report on the environmental quality standards for Bangladesh. Personal communication to Department of Environment (DoE), Ministry of Environment and Forest (MoEF), Dhaka, Bangladesh.

DoE (Department of Environment). 2011. Report on the environmental quality standards for Bangladesh. Personal communication to Department of Environment (DoE), Ministry of Environment and Forest (MoEF), Dhaka, Bangladesh.

ECR (The Environment Conservation Rules). 1997. The Environmental Conservation Rules, Government of the people`s republic of Bangladesh. Ministry of Environment and Forest (MoEF).. 205-207pp.

Emongor, V.; Nkegbe, E.; Kealotswe, B.; Koorapetse, I.; Sankwasa, S. and Keikanetswe, S. 2005. Pollution in Gaborone Industrial Effluent. Journal ofApplied Sciences, 5(1): 147-150. red and they do not use decoloring reagent to remove the color which obstructs the photosynthesis process of phytoplankton. Pollution causes deterioration in the quality of the water, making it unfit for its chosen use. Natural waterways normally contain micro-organisms, which enable them to undergo self-purification. The existing tendency of industrialization and urbanization decreases the non-renewable resources and disrupts the surface water quality through indiscriminate disposal of industrial effluents and other toxic wastes which the major environmental issues are posing threats to the existence of human being.

(BUET), Bangladesh, and the Fakir Knitwear Ltd., for their kind assistance during the study period.

EQS (Environmental Quality Standard). 1997. Bangladesh Gazette, Registered nr. DA-1, Ministry of Environment and Forest (MoEF), Government of the people's republic of Bangladesh.

Government of People's Republic of Bangladesh, Ministry of Environment and Forests, The Environment Conversation Rules 1997, Schedule 10, Rule 13 (Unofficial English Version).

Gupta, P. K. 2001. Methods in Environmental Analysis: Water, Soil and Air. Agro-bios Publication. India.

Huq, S. M. I. and Alam, M. D. 2005. A hand book of analysis of Soil, Plant and Water. BACERDU, University of Dhaka, Bangladesh. 246p.

Islam, M. O.; Khan,M. H. R.; Das,A. K.; Akhtar, M. S.; Oki, Y. and Adachi, T. 2006. Impacts of industrial effluents on plant growth and soil properties. Soil \& Environ., 25(2):113-118.

Meady, J. W. 1998. Aquaculture Management, India. CBS Publishers and Distributors. 9p.

Metcalf and Eddy. 2003. Waste Water Engineering Treatment Disposal Reuse, $4^{\text {th }}$ edition, McGraw-Hill, New York.

Momtaz, H.; Alam, A. K .M. R. and Hoque, S. 2010. A comparative study of phytoplankton diversity in relation to water quality of migratory birds visiting and non-visiting wetlands of Savar. Bangladesh Journal of Environmental Research, 8: 31-38.

Nuruzzaman, M. A.; Islam, S. M.;Ullah, M. H.; Rashid and Gerzabek, M.H. 1998.Contamination of soil environment by the tannery industries. Bangladesh Journal of Soil Science, 25: 1-10.

Senthil, P.; Jeyachandran, S.; Manoharan, C. and Vijayakumar, S. 2012. Microbial diversity in rubber industry effluent. Int. J. Pharm. Biol. Sci., 2:123-131.

Sultana, Z., Ershad, M., Uddin S. and M. M. Haque. 2013. Study on implementation of effluent treatment plants for safe environment from textile waste. Journal of Research in Environmental Science and Toxicology, 2(1):9-16.

Trivedy, R. K. and Goel P. K. 1984. Chemical and biological methods for water pollution studies. Environmental publications, KARAD. pp. 42-74. 